\title{
LIPASE IMMOBILIZATION ON FIBERS GRAFTED WITH POLYGLYCIDYL METHACHRYLATE
}

\author{
MA'An FAHMi Rashid AlKhatib ${ }^{1 *}$ NiK AdLin BAHRUdin ${ }^{1}$, HAMZAH MOHD. \\ SAlleh $^{2}$, Mohamed Mahmoud Elsayed NaSeF ${ }^{3}$, Teo Ming Ting ${ }^{4}$ \\ ${ }^{1}$ Department of Biotechnology Engineering, Faculty of Engineering, \\ ${ }^{2}$ International Institute for Halal Research and Training (INHART), \\ International Islamic University Malaysia, \\ PO Box 10, Kuala Lumpur 59728, Malaysia53100 Gombak, Selangor, Malaysia. \\ ${ }^{3}$ Chemical Engineering Department, Universiti Tecknologi Petronas, \\ 32610 Seri Iskandar, Perak, Malaysia. \\ ${ }^{4}$ Radiation Processing Technology Division, Malaysia Nuclear Agency, \\ Bangi, 43000 Kajang, Selangor, Malaysia. \\ *Corresponding author: maan@iium.edu.my
}

(Received:27th Sept 2018; Accepted:20 th Dec 2018; Published on-line: $1^{\text {st }}$ June 2019)

https://doi.org/10.31436/iiumej.v20i1.1002

\begin{abstract}
Lipase enzyme originated from wheat germ was immobilized on nylon -6grafted with polyglycidyl methachrylate (PGMA). The immobilization of enzyme experiments were designed and studied using face centred central composite design (FCCCD) under response surface methodology (RSM). Prior to immobilization, the polymer was activated with diethyl amine/ethanol to introduce an amine functional group to facilitate covalent bonding with the enzyme. The immobilized and free enzymes were characterized for effect of temperature and $\mathrm{pH}$ on enzyme activity, stability, storage and reusability as well as kinetics studies. ANOVA revealed that optimum lipase activity of $0.287 \mathrm{U} / \mathrm{ml}$ was achieved at immobilization time of $5 \mathrm{~h}, \mathrm{pH}$ of 6 and $1.0 \mathrm{mg} / \mathrm{ml}$ for enzyme concentration. The optimum temperatures and $\mathrm{pH}$ for immobilized and free enzymes were $45{ }^{\circ} \mathrm{C}$ and $35^{\circ} \mathrm{C}$, and 8 and 7 , respectively. The immobilized enzyme showed higher stability compared to free enzyme. The immobilized enzyme retained $18 \%$ of its activity after being recycled 8 times. In a storage stability test, immobilized lipase was able to retain $70 \%$ of its activity after being stored for 30 days, while free enzyme activity dropped to $15 \%$ after 20 days of storage.
\end{abstract}

ABSTRAK:Enzim Lipase telah dihasilkan daripada mikroorganisma pegun gandum di atas nilon -6- dan digraf bersama poliglisidel methakrilet (PGMA). Enzim pegun ini direka dan dikaji secara eksperimen menggunakan reka bentuk campuran pusat pada permukaan (FCCCD) di bawah kaedah tindak balas permukaan (RSM). Sebelum menjadi pegun, polimer ini telah diaktifkan dengan dietil amine/ethanol bagi menghasilkan kumpulan fungsi amine bagi membantu ikatan kovalen atom pada enzim. Enzim pegun dan bebas ini telah dikategorikan mengikut kesan enzim ke atas suhu, aktiviti enzim ke atas kesan $\mathrm{pH}$, kestabilan, keboleh-simpanan dan keboleh-gunaan balik, serta ujian tindak balas kinetik. ANOVA membuktikan bahawa aktiviti optimum enzim lipase ini adalah sebanyak 0.287 $\mathrm{U} / \mathrm{ml}$ telah terhasil selama 5 jam pegun, pada $\mathrm{pH} 6$ dan kepekatan enzim sebanyak 1.0 $\mathrm{mg} / \mathrm{ml}$. Suhu dan $\mathrm{pH}$ optimum, pada enzim pegun dan enzim bebas ini adalah pada $45^{\circ} \mathrm{C}$ dan $35^{\circ} \mathrm{C}$, dan $\mathrm{pH} 8$ dan 7, masing-masing. Enzim pegun ini menunjukkan lebih stabil daripada enzim bebas. Enzim pegun dilihat kekal 18\% daripada aktivitinya selepas 8 kali ulangan. Melalui ujian kestabilan simpanan, enzim lipase pegun dapat mengekalkan 70\% 
daripada aktivinya selepas disimpan selama 30 hari, manakala aktiviti enzim bebas telah menurun kepada 15\% selepas 20 hari dalam simpanan.

KEYWORDS: immobilization; enzyme; lipase; optimization; FCCCD; RSM; fibers; nylon; stability; reusability; kinetics study

\section{INTRODUCTION}

Lipases (triacylglycerol ester hydrolase, EC 3.1.1.3) play an important role in industry. Their capability to break triacylglycerols down to fatty acids and glycerol make them the most promising in biodiesel production using transesterification of oils. Lipase is also used in food and flavour making, drug synthesis, and perfumery and cosmetics [1]. Due to the shortcomings of free enzymes, such as having low stability, non-reusability and difficulty in separation from the products, immobilization technology is introduced to overcome these drawbacks. Immobilization of enzymes is the most frequently used method to convey the needed characteristics of conventional heterogeneous catalysts into biological catalysts [2]. Various mechanisms are applied to immobilize enzymes such as covalent binding physical adsorption, ionic interaction, or entrapment [3]. Numerous benefits are conceivable through immobilization including improved stability, reusability, ease in separation of final products, greater control in catalysis [4], considerable cost benefits for industrial processes [5], and the ability to stop the reaction quickly by removing the enzyme from the reaction solution [6].

Among many supports, immobilization on polymer support has gained more interest. Polymer supports have good mechanical properties, can be produced in mass quantities and can be easily modified for immobilization with maintained stability [7,8]. Several studies showed that lipase enzymes have been immobilized on different types of support including chitosan beads [9], Electrospun cellulose nanofiber membrane [10] Sepabeads ${ }^{\circledR}$ [11], ferric silica nanocomposite [12] and octyl and cyanogen bromide (CNBr) agarose beads [13].

Radiation-induced graft polymerization (RIGP) is a useful method to functionalize various polymer materials [14]. Nylon-6, which is also known as polycaprolactam and polyamide 6 , possesses excellent mechanical and physical properties and has become the most widely used synthetic polymer for fibres [15]. Introducing functional groups on the Nylon-6 polymer surface with RIG can introduce new chemical characteristics to the polymer while its main properties remain unchanged [16] making it promising candidate for enzyme immobilization.

In this study, lipase enzyme was immobilized onto the nylon-6 grafted polyglycidyl methachrylate (PGMA) with covalent linkage. Three conditions, namely, reaction $\mathrm{pH}$, reaction time, and enzyme/support ratio were optimized using response surface methodology (RSM) and face centred central composite design (FCCCD). The optimum temperature and $\mathrm{pH}$, thermal stability, storage stability and reusability, as well as kinetic parameters were determined.

\section{MATERIALS AND METHODS}

\subsection{Material}

Nylon-6 polymer was purchased from Reliance Sdn. Bhd. GMA, polyoxyethylene sorbitanmonolaurate or Tween-20 and diethyl amine (DEA) were purchased from SigmaAldrich (USA). Lipase (solid form, 5-15 units/mg protein) from wheat germ was also procured from Sigma-Aldrich (USA). All reagents used were of analytical grade or higher 
and used as procured.

\subsection{Synthesis and Activation of Polymer}

Nylon-6-grafted with PGMA was synthesized by radiation-induced emulsion graft copolymerization. Typically, nylon-6 samples were placed in a PE zipper bags which were purged using purified N2, sealed and irradiated using an electron beam accelerator (EPS 3000 ) to a total dose of $10 \mathrm{kGy}$. The deoxygenated grafting solution was transferred to an ampoule containing irradiated polymer. PGMA grafted onto nylon- 6 with grafting yield of $280 \%$ was obtained using grafting solution containing a mixture of $5 \mathrm{wt} \%$ of GMA and 0.5 wt $\%$ of Tween 20 in DI water with reaction time 3 hours at $40{ }^{\circ} \mathrm{C}$. Nylon-6-grafted with PGMA was introduced with the amine group where the PGMA-fiber was treated with diethyl amine/ethanol solution $(1: 1, \mathrm{v} / \mathrm{v})$ at $40{ }^{\circ} \mathrm{C}$ for 4 hours with $100 \mathrm{rpm}$ agitation. The aminated fiber was taken out of the solution using forceps and washed several times with absolute ethanol then dried for 2 hours at $60{ }^{\circ} \mathrm{C}$ in oven. After the drying process, the amine group density was calculated by Eq. (1) [14]:

$$
\text { Amine group density }\left(\frac{\text { mmole }}{\text { gram }}-\text { adsorption }\right)=\left[\frac{(W f-W g)}{W f}\right] \times\left(\frac{1000}{\mathrm{MW}}\right)
$$

where $W_{g}$ and $W_{f}$ are the weights of nylon-6 grafted PGMA before and after amination and MW is the molecular weight of diethyl amine. The aminated fiber then was soaked in hydrochloric acid solution (1M) followed by sodium hydroxide solution (1M) overnight. Then, the aminated fiber underwent oven drying for 2 hours at $60{ }^{\circ} \mathrm{C}$ and was stored in a desiccator to avoid moisture.

\subsection{Statistical Optimization for Lipase Immobilization}

Statistical optimization is a practical approach for studying several factors associated with the production process. This method is commonly used in reducing the number of experiments and for quick screening of the experimental field. Statistical evaluation of the data from an appropriately designed set of experiments can demonstrate the form of interaction between the parameters. In this study, Design Expert software (version 7.0.0) has been chosen to analyse the process parameters that influence the immobilization of lipase.

A 3-factor and 3-level face centered central composite design (FCCCD) under RSM was employed in this study. The effect of immobilization time (x1), immobilization $\mathrm{pH}\left(\mathrm{x}_{2}\right)$, and enzyme/support ratio $\left(\mathrm{x}_{3}\right)$ on lipase activity was evaluated at immobilization time of 2$10 \mathrm{~h}$; $\mathrm{pH}$ of 6-8; and an enzyme concentration of $0.4-1.0 \mathrm{mg} / \mathrm{ml}$.

Analysis of Variance (ANOVA) results were used to analyse the statistical data. This analysis included the Fischer's F-test, p-Value (which is used to indicate statistical significance for each of the coefficients tested and is also important to understand the pattern of the mutual interactions between the parameters), and the coefficient of determination $\mathrm{R}^{2}$ (that measures the fit of the regression model). A value of $\mathrm{R}^{2}$ closer to 1 indicates there are outstanding correlations between the independent variables. The $\alpha$ - level was set at 0.05 intervals, a p-value which is less than this value indicates that the model terms are significant. 


\subsection{Immobilization of Lipase Enzyme}

Immobilization of lipase onto polymer support was carried out by immersing $20 \mathrm{mg}$ of activated polymer in various concentrations of lipase $(0.4 \mathrm{mg} / \mathrm{ml}, 0.7 \mathrm{mg} / \mathrm{ml}$ and $1.0 \mathrm{mg} / \mathrm{ml})$ in a phosphate buffer solution (PBS) $(50 \mathrm{mM}, \mathrm{pH} 7)$ and the mixture was incubated at 28 $37^{\circ} \mathrm{C}$ with $100 \mathrm{rpm}$ agitation for different times (2, 6, $12 \mathrm{~h}$ ). Protein concentration in final solution was measured by Bradford protein assay [17]. The amount of lipase immobilized was calculated based on the difference in lipase initial and final concentrations. The recovery efficiency (RE) was defined as "the percentage of enzymes on the polymer by detecting the protein concentration before and after immobilization" [18]. The RE value is calculated according to Eq. (2):

$$
R E=\frac{C p, o-C p, r}{C p, o} \times 100 \%
$$

where, $\mathrm{C}_{\mathrm{p}, \mathrm{o}}$ is the protein concentration of added lipase $(\mathrm{mg}$ protein $/ \mathrm{mL}) ; \mathrm{C}_{\mathrm{p}, \mathrm{r}}$ is the protein concentration of lipase in the solution and washed water after immobilization (mg $\operatorname{protein} / \mathrm{mL})$.

\subsection{Measurement of lipase activity}

The activity of lipase enzyme was found by employing $p$-nitrophenyl palmitate ( $p$-NPP) as a substrate. Stock solution consisted of $28 \mathrm{mg}$ of dissolved $p$-NPP in $100 \mathrm{ml}$ of Triton X100 and $1.7 \mathrm{ml}$ of $1 \%$ sodium dodecyl sulfate while stirring. Then the solution mixture was heated on a hot plate until the solution become clear and no turbidity was seen. To start the enzymatic reaction, $1 \mathrm{~mL}$ of $p$-NPP stock solution was incubated with $1 \mathrm{~mL}$ of $0.1 \mathrm{M}$ Tris$\mathrm{HCl}\left(\mathrm{pH}\right.$ 8.2) and $20 \mathrm{mg}$ immobilized enzyme at $37^{\circ} \mathrm{C}$ for $30 \mathrm{~min}$. Then, $1 \mathrm{~mL} \mathrm{NaOH}(1 \mathrm{M})$ was added to stop the enzyme reaction. The molar extinction coefficient for $p$-nitrophenol is $15,000 \mathrm{M}^{-1} \mathrm{~cm}^{-1}$ at $311 \mathrm{~nm}$. Manifestly, one unit (U) of enzyme activity is defined as the amount of enzyme that liberates $1 \mathrm{mmol} p$-nitrophenol per minute under assay condition.

\subsection{Effect of Temperature and pH on Enzyme Activity}

The immobilized enzyme (20 mg matrix) was placed in phosphate buffer $(0.1 \mathrm{M}, \mathrm{pH}$ 7) and assayed for residual lipase activity at different temperatures $\left(25-65^{\circ} \mathrm{C}\right)$. For $\mathrm{pH}$, the same amount of enzyme was assayed in 0.1 M PBS at pH range of (5-9).

\subsection{Stability Profile of Immobilized Lipase}

The $\mathrm{pH}$ stability of immobilized lipase was studied by incubating the enzyme for 30 minutes without addition of substrate in buffers of varying $\mathrm{pH}$ in the range of (5-12). After the incubation period, the residual enzyme activity was evaluated. Residual activities were calculated as the ratio of the activity of immobilized enzyme after incubation to the activity at the optimum reaction $\mathrm{pH}$.

Thermal stability of immobilized lipase was tested by incubating the immobilised enzyme at varying temperatures in the range of $20-60{ }^{\circ} \mathrm{C}$ for 30 minutes at $\mathrm{pH} 7$ and determining the activity at its optimum reaction temperature. Relative residual activity was measured by setting the highest activity at $100 \%$.

\subsection{Reusability of Immobilized Lipase}

Immobilized lipase was washed thrice with PBS $(50 \mathrm{mM}, \mathrm{pH} 7)$ to remove residual substrate. Enzyme activity was assayed at $45{ }^{\circ} \mathrm{C}$ for up to eight times. The residual activity was determined by taking the first activity cycle as $100 \%$. 


\subsection{Storage Study}

Immobilized lipase and free lipase were stored in PBS $(50 \mathrm{mM}, \mathrm{pH} 7)$ at $4{ }^{\circ} \mathrm{C}$ for up to 30 days. The remaining activity was measured on a weekly basis.

\subsection{Kinetics Study}

Kinetic parameters of immobilized and free lipase were performed in phosphate buffer $(50 \mathrm{mM}, \mathrm{pH} 7)$ at $45^{\circ} \mathrm{C}$. To evaluate the value of kinetic parameters which are $K_{\mathrm{M}}$ and $V_{\max }$, the concentration of $p$-NPP substrate was varied in the range (0.1-3.0 mM). A few plots were utilized to determine $K_{\mathrm{M}}$ and $V_{\max }$ of the enzyme. The best fitted plot was selected from the highest $\mathrm{R}^{2}$ value.

\section{RESULTS AND DISCUSSION}

\subsection{Optimization of Lipase Immobilization}

The optimization of the lipase immobilisation on nylon-6 polymer was conducted using response surface methodology (RSM) under face centred central composite design (FCCCD). The agitation was set up at $100 \mathrm{rpm}$ and temperature of $37^{\circ} \mathrm{C}$. The highest immobilized lipase activity was $0.222 \mathrm{U} / \mathrm{mL}$ obtained at $\mathrm{pH} \mathrm{7,6} \mathrm{hrs}$ immobilization time, and enzyme concentration of $0.70 \mathrm{~g} / \mathrm{mL}$. The lowest activity of $0.004 \mathrm{U} / \mathrm{mL}$ was at $\mathrm{pH} 7,6$ hrs immobilization time, and enzyme concentration of $0.40 \mathrm{mg} / \mathrm{mL}$.

The effect of each factor and its interactions were calculated using a Design Expert program (version 7.0.0, Stat-Ease Inc., USA). As the data was fitted with several models and consequently investigated using analysis of variance (ANOVA), the results showed that the quadratic polynomial model is the most acceptable to describe immobilization of lipase. The mathematical prediction model for immobilization of lipase was derived (Eq. (3)) under ANOVA test as below

$$
\begin{aligned}
Y= & -1.00+0.052 x_{1}-0.19 x_{2}+0.37 x_{3}-0.18 x_{1} x_{2}-0.42 x_{1} x_{3}-0.12 x_{2} x_{3}- \\
& 0.52 x_{2}^{2}-0.27 x_{3}^{2}
\end{aligned}
$$

where $x_{1}$ is immobilization $\mathrm{pH}, x_{2}$ is the immobilization time and $x_{3}$ is the enzyme concentration.

ANOVA results are shown in Table 1. The model F-value of 11.60 implies the model is significant. There is only a $0.02 \%$ chance that a "Model F-Value" this large could occur due to noise. Values of "Prob $>$ F" less than 0.05 indicate model terms are significant. Meanwhile, lack of fit value (0.1088) was insignificant with respect to pure error. This indicated a good and reliable model. Thus, it could be used as a target response. The coefficient of determination $\left(\mathrm{R}^{2}=0.894\right)$ also indicated good correlation between the independent variables.

Figure 1 shows the 3D plot of the interaction between enzyme concentration and time. It can be observed that there is increase in enzyme activity with concentration; however, the highest enzyme activity is attained at medium time. At longer immobilization time the activity decreases substantially. 


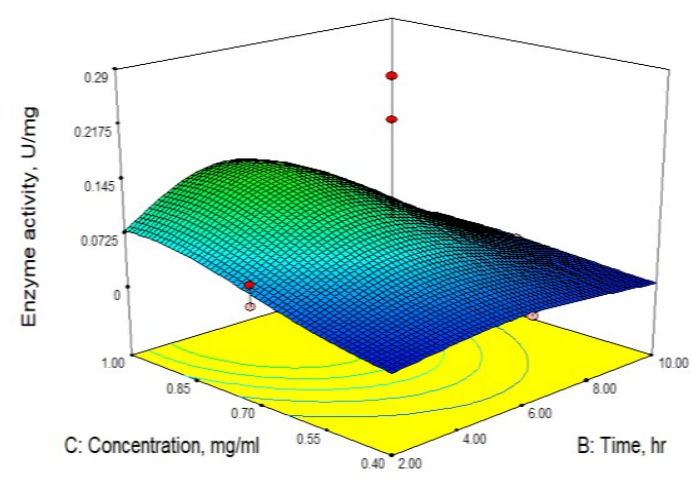

Fig. 1: 3D surface plot of enzyme concentration and time vs enzyme activity

Table 1 Analysis of variance (ANOVA) for immobilized enzyme

\begin{tabular}{cccc}
\hline Source & F Value & $\begin{array}{c}\text { p-value } \\
\text { Prob > F }\end{array}$ & Remarks \\
\hline Model & 11.6 & 0.0002 & significant \\
A-pH & 0.3 & 0.6216 & \\
B-Time & 2.5 & 0.1436 & \\
C-Concen. & 9.0 & 0.0120 & \\
AB & 1.5 & 0.2519 & \\
AC & 7.9 & 0.0168 & \\
BC & 0.8 & 0.3774 & \\
B & 24.9 & 0.0004 & \\
C $^{2}$ & 6.8 & 0.0244 & \\
Lack of Fit & 2.9 & 0.1088 & not \\
R $^{2}$ & 0.89 & & \\
\hline
\end{tabular}

\subsection{Model Validation for Immobilized Lipase Optimization}

The accuracy of the model was validated under the optimal conditions obtained from FCCCD. The response (enzyme activity) was set at maximum. The validation test was performed by choosing three random runs according to Table 2. Based on the validation test, since the model is significant, lack of fit is insignificant and percentage error is low, it could be concluded that the model was reliable and reproducible.

Table 2 Validation test on optimization of immobilized lipase

\begin{tabular}{cccccc}
\hline \multicolumn{3}{c}{ Parameters } & \multicolumn{3}{c}{$\begin{array}{c}\text { Immobilized enzyme } \\
\text { activity (U/mL) }\end{array}$} \\
\hline $\mathrm{pH}$ & $\begin{array}{c}\text { Time } \\
(\mathrm{h})\end{array}$ & $\begin{array}{c}\text { Enzyme } \\
\text { concen } \\
(\mathrm{mg} / \mathrm{mL})\end{array}$ & Pred & Exper & $\begin{array}{c}\text { Error } \\
(\%)\end{array}$ \\
& & 0.90 & 0.145 & 0.133 & 9.49 \\
7 & 4.94 & 0.90 & 0.146 & 0.130 & 12.00 \\
7 & 4.99 & 0.145 & 0.125 & 15.87 \\
\hline 7 & 5.03 & 0.90 & 0.125 & & \\
\hline
\end{tabular}

\subsection{Optimum Temperature and pH of Immobilized Lipase Activity Assay}

The optimum temperature for free lipase was at $35^{\circ} \mathrm{C}$ whereas for immobilised lipase, the maximum activity was at $45^{\circ} \mathrm{C}$ as shown in Fig. 2 . The optimum temperature profile of 
the immobilized lipase was broader compared to the free lipase. This may be due to the decrease in conformational mobility of immobilized lipase because of the covalent bonding between the enzyme and polymer [19]. The free lipase lost almost $60 \%$ of its activity when exposed to temperatures above $35{ }^{\circ} \mathrm{C}$. This low residual activity may be attributed to a significant amount of enzyme being denatured when exposed to elevated temperature [20]. Free lipase is denatured when heated at above $45^{\circ} \mathrm{C}$ [21]. Other studies supported improved thermostability of the immobilized lipase as compared to free enzyme including [10] and [21].

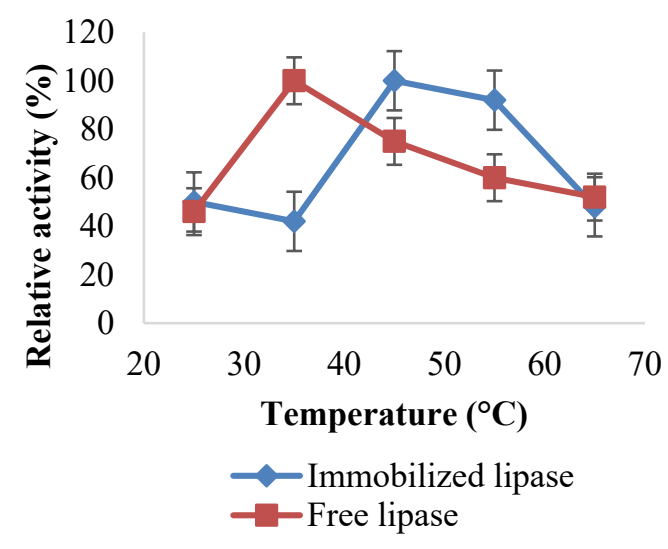

Fig. 2: Optimum temperatures for both immobilized and free lipase.

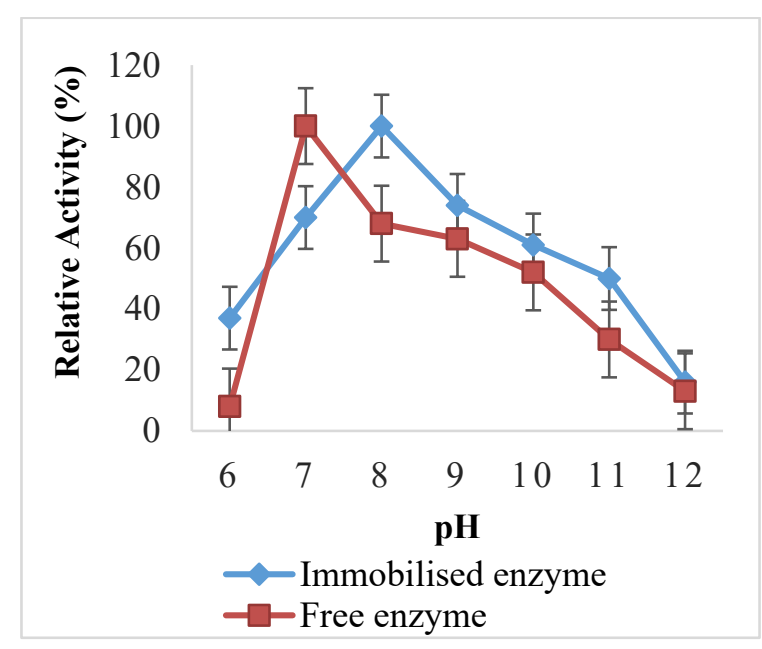

Fig. 3: Optimum $\mathrm{pH}$ for both immobilized and free lipase.

The optimum $\mathrm{pH}$ for free lipase was at $\mathrm{pH} 7$, as shown in Fig. 3. This may result from the ionization states of several groups on amino acid chains that result in suitable conformation of lipase molecules [22]. After immobilization, the maximum activity was observed at $\mathrm{pH}$ 8. This alkaline shift could be an effect from the alteration in the microenvironment of the enzyme caused by immobilization on the support system [17].

\subsection{Thermal Stability of Immobilized Lipase}

Figure 4 shows the thermal stability of immobilized and free lipase. It can be seen that when increasing the temperature to $55^{\circ} \mathrm{C}$, the immobilized enzyme retained $74 \%$ of its activity compared to free lipase, which dropped to $18 \%$ residual activity. This result indicated that the immobilized enzyme was more stable than its free counterpart at higher 
temperatures. Zhu and Sun [19] proposed that enhanced thermal stability was a result of covalent attachment, which limited conformational change and disallowed the denaturation process of the immobilized lipase at higher temperature. For free enzyme, high temperature might interrupt the globular structure of the proteins thus leading to the denaturation [23].

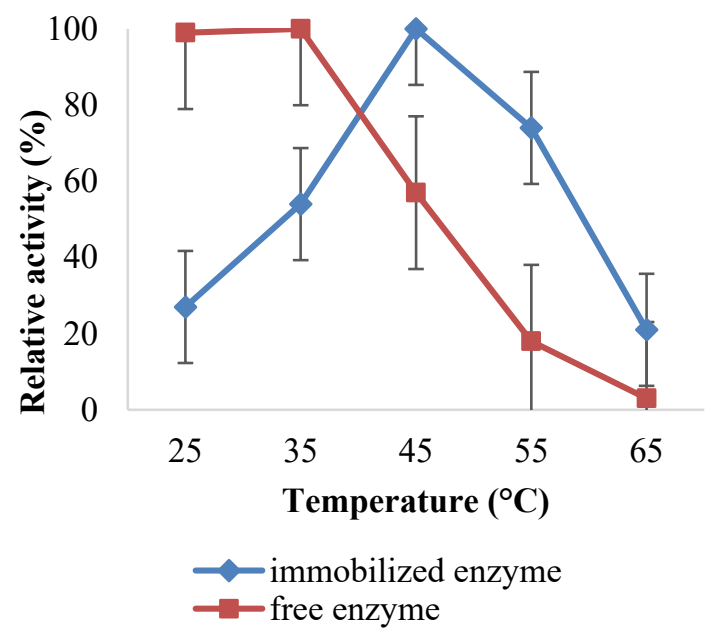

Fig. 4: Thermal stability of immobilized and free lipase.

\section{5 pH Stability of Immobilized Lipase}

Figure 5 compares $\mathrm{pH}$ stability of immobilized and free lipase. It can be clearly seen that immobilized lipase has better $\mathrm{pH}$ stability within the alkaline region, from $\mathrm{pH} 8$ to $\mathrm{pH}$ 12. Pahujani et al. [24] reported that the immobilized lipase was fairly stable within $\mathrm{pH} 7.5$ - 9.5. Lipase from a mutant strain of Cornebacterium sp. was immobilized and has been found stable at $\mathrm{pH} 8$ [25]. According to [19], the multipoint attachment mechanism limits the undesired conformation against environment changes. This improves $\mathrm{pH}$ stability of the immobilized lipase.

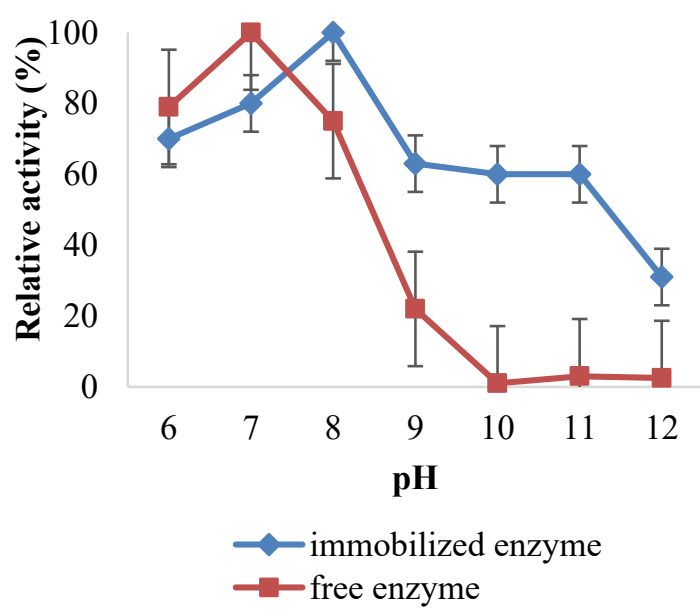

Fig. 5: pH stability of immobilized and free lipase.

\subsection{Reusability of Immobilized Lipase}

Figure 6 shows the effect of repeated use on the activity of immobilized lipase. In this study, the reusability test was conducted up to 8 cycles. The first cycle of this test was set as $100 \%$ and the residual activity of each cycle was calculated based on it. According to Fig. 6 , immobilized lipase retained $78 \%$ of its residual activity up to 4 cycles. After 8 cycles, the 
residual activity dropped to $18 \%$. Previous study reported that lipase immobilized on CNBractivated-Sepharose 4B retained full activity even after 13 cycles [26]. Huang et al. [22] reported that the remaining activity of lipase immobilized on the cellulose fibrous membrane dropped to $30 \%$ after 8 cycles. The activity of immobilized enzyme tends to decrease with repeated use. The loss of activity could be related to the inactivation of enzyme by continuous use and the leakage of protein from the polymer support. This can be improved by providing a stronger attachment mechanism in order to increase the recyclability.

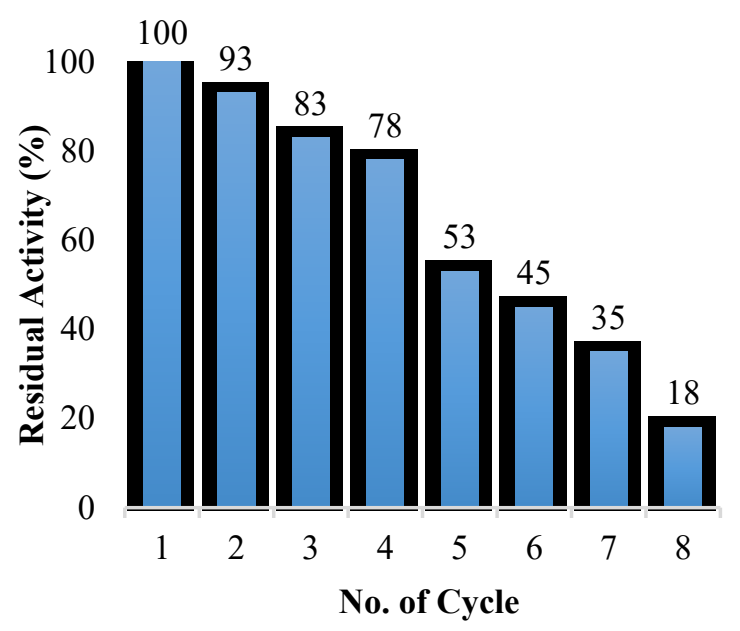

Fig. 6: Reusability of immobilized lipase.

\subsection{Storage Stability of Immobilized Lipase}

The stability of immobilized and free lipase was compared with respect to storage time. Both free and immobilized lipases were stored at $4{ }^{\circ} \mathrm{C}$ for 35 days then the activities of both enzymes were determined. The immobilized lipase was found to retain $70 \%$ of its residual activity after 30 days of storage. On the other hand, after 20 days of storage at $4{ }^{\circ} \mathrm{C}$, the activity of free lipase solution dropped to $15 \%$ of its original activity (Fig. 7). According to [19] free enzyme solution undergoes rapid reductions in catalytic activity during storage, making it difficult to recover the enzyme from the reaction mixture after catalytic reactions. This result shows the great potential of the polymer used in this study as a support for enzyme immobilization.

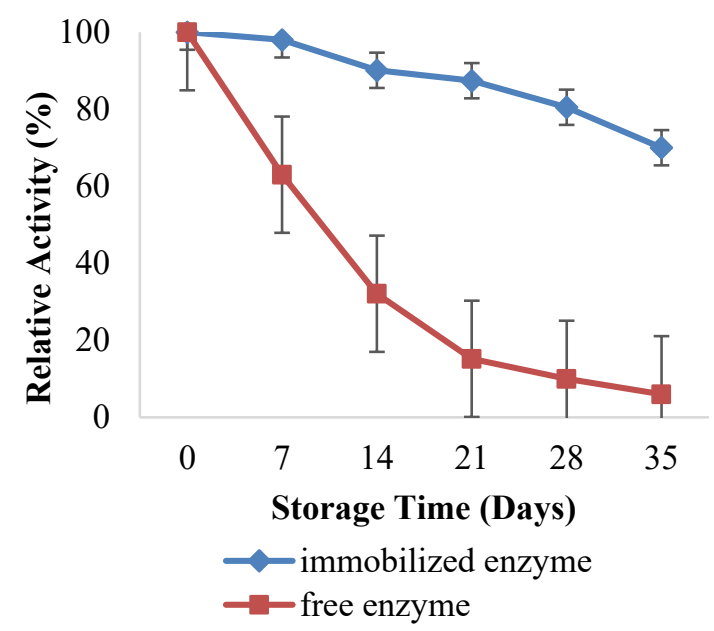

Fig. 7: Storage stability test of immobilized and free lipase. 


\subsection{Kinects Study}

For the kinetics study of immobilized and free lipase enzyme, a Lineweaver-Burk Plot best fitted the data (Fig. 8). It was found that both $V_{\max }$ and $K_{\mathrm{M}}$ for immobilized lipase were reduced compared to the free enzymes. $V_{\max }$ and $K_{\mathrm{M}}$ values obtained were $0.012 \mathrm{mM} / \mathrm{min}$ and $7.250 \mathrm{mM}$ for immobilized lipase, and 0.024 and 10.321 for free lipase, respectively. The lower value of $K_{\mathrm{M}}$ for immobilized lipase enzyme compared to free enzyme indicates a stronger and more efficient binding of substrate. $V_{\max }$, on the other hand, exemplifies how quick the reaction is catalyzed by the enzyme. Lower $V_{\max }$ for the immobilized enzyme designates lower enzyme rate. This is commonly observed since the enzyme having lower activity after the immobilization process is caused by the lower accessibility of substrates towards the immobilized enzyme's active site [19].

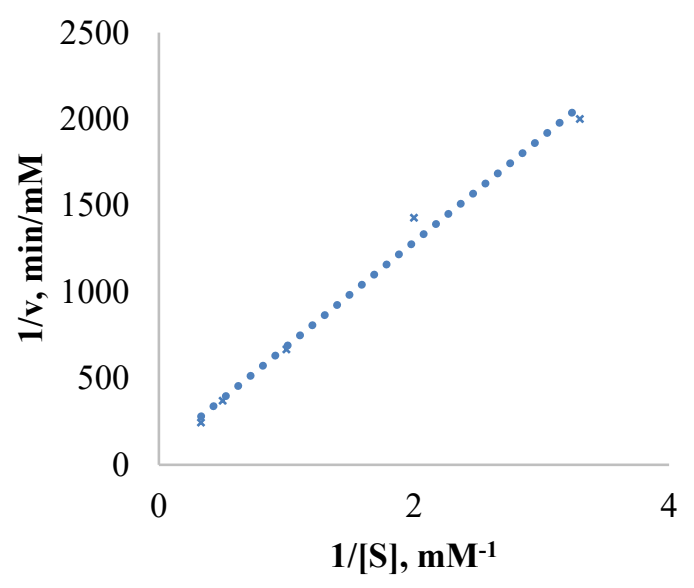

Fig. 8: Lineweaver-Burk Plot for immobilized lipase.

\section{CONCLUSIONS}

Lipase enzyme was successfully immobilized on nylon-6-grafted with PGMA. The optimum immobilization conditions were determined using RSM FCCCD. Immobilized enzyme showed higher stability at wide range of temperature and $\mathrm{pH}$. Immobilized lipase retained $70 \%$ of its activity when stored for 35 days at $4{ }^{\circ} \mathrm{C}$, while free lipase lost $70 \%$ after 14 days. The immobilized lipase retained $78 \%$ of its activity after 4 cycles. This proposed immobilized enzyme-polymer system has potential in applications such as biodiesel production from oil.

\section{ACKNOWLEDGMENT}

The authors wish to acknowledge the financial support from a research grant (FRGS 14162-0403) obtained under the Fundamental Research Grants Scheme, Ministry of Higher Education (MOHE), Malaysia. The authors are also grateful to Hazimah Akbar Tajudin for her valuable input on statistical analysis in this manuscript.

\section{REFERENCES}

[1] Hung TC, Giridhar R,Chiou SH, Wu WT. (2003). Binary immobilization of Candida rugosa lipase on chitosan. J. Mol. Catal. B Enzym., 26: 69-7.8

[2] Won K, Kim S, Kim KJ, Park HW, Moon SJ. (2005). Optimization of lipase entrapment in Ca-alginate gel beads. Process Biochem., 40: 2149-2154. 
[3] Yujun W, Jian X, Guangsheng L, Youyuan D. (2008). Immobilization of lipase by ultrafiltration and cross-linking onto the polysulfone membrane surface. Bioresour. Technol., 99: 2299-2303.

[4] Singh BD. (2009). Biotechnology: Expanding Horizons. India Kalyani

[5] Alkhatib M. (2011). Enzymatic hydrolysis of oil palm empty fruit bunch using immobilized cellulase enzyme. African J. Biotechnol., 10: 18811-18815.

[6] Alkhatib M, Alam Z, Mohammed R. (2012). Statistical modelling optimisation of cellulase enzyme immobilisation on functionalised multi-walled carbon nanotubes for empty fruit bunches degradation. Aust. J. Basic Appl. Sci., 6: 30-38.

[7] Bowers LD, Carr PW. (1976). Applications of Immobilized Enzymes in Analytical Chemistry. Anal. Chem., 48: 544A-559A.

[8] Lu J, Toy PH. (2009). Organic polymer supports for synthesis and for reagent and catalyst immobilization. Chem. Rev., 109: 815-838.

[9] Chiou SH, Wu WT. (2004). Immobilization of Candida rugosa lipase on chitosan with activation of the hydroxyl groups. Biomaterials. 25: 197-204.

[10] Huang X-J, Chen P-C, Huang F, Ou Y, Chen M-R, Xu ZK. (2011). Immobilization of Candida rugosa lipase on electrospun cellulose nanofiber membrane. J. Mol. Catal. B Enzym., 70: 95-100.

[11] Prlainović NŽ, Knežević-Jugović ZD, Mijin DŽ, Bezbradica DI. (2011). Immobilization of lipase from Candida rugosa on Sepabeads ${ }^{\circledR}$ : The effect of lipase oxidation by periodates. Bioprocess Biosyst. Eng., 34: 803-810.

[12] Tran DT, Chen CL, Chang JS. (2012). Immobilization of Burkholderia sp. lipase on a ferric silica nanocomposite for biodiesel production. J. Biotechnol. 158: 112-119.

[13] Manoel EA, dos Santos JCS, Freire DMG, Rueda N, Fernandez-Lafuente R. (2015). Immobilization of lipases on hydrophobic supports involves the open form of the Enzyme. Enzyme Microb. Technol. ,71: 53-57.

[14] Nasef MM, Güven O. (2012). Radiation-grafted copolymers for separation and purification purposes: Status, challenges and future directions. Prog. Polym. Sci., 37: 1597-1656. http://dx.doi.org/10.1016/j.progpolymsci.2012.07.004

[15] Liu Y, Cui L, Guan F, Gao Y, Hedin NE, Zhu L, Fong H. (2007). Crystalline morphology and polymorphic phase transitions in electrospun nylon-6 nanofibers. Macromolecules. 40: 6283-6290.

[16] Nasef MM, Abbasi A, Ting TM. (2014). New $\mathrm{CO}_{2}$ adsorbent containing aminated poly(glycidyl methacrylate) grafted onto irradiated PE-PP nonwoven sheet. Radiat. Phys. Chem., 103: 72-74. http://dx.doi.org/10.1016/j.radphyschem.2014.05.031

[17] Bradford MM. (1976). A rapid and sensitive method for the quantitation of microgram quantities of protein utilizing the principle of protein-dye binding. Anal. Biochem., 72: 248254.

[18] Liu C-H, Lin Y-H, Chen C-Y, Chang J-S. (2009). Characterization of Burkholderia lipase immobilized on celite carriers. J. Taiwan Inst. Chem. Eng., 40: 359-363.

[19] Zhu J, Sun G. (2012). Lipase immobilization on glutaraldehyde-activated nanofibrous membranes for improved enzyme stabilities and activities. React. Funct. Polym., 72: 839845.

[20] Yu CY, Li XF, Lou WY, Zong MH. (2013). Cross-linked enzyme aggregates of Mung bean epoxide hydrolases: A highly active, stable and recyclable biocatalyst for asymmetric hydrolysis of epoxides. J. Biotechnol., 166: 12-19. doi: 10.1016/j.jbiotec.2013.04.015

[21] Yuce-Dursun B, Cigil AB, Dongez D, Kahraman MV, Ogan A, Demir S. (2016). Preparation and characterization of sol-gel hybrid coating films for covalent immobilization of lipase enzyme. J. Mol. Catal. B Enzym., 127: 18-25.

[22] Huang XJ, Chen PC, Huang F, Ou Y, Chen MR, XZ. (2011). Immobilization of Candida rugosa lipase on electrospun cellulose nanofiber membrane. J Mol Catal B-Enzym., 70: 95100.

[23] Gupta K, Jana AK, Kumar S, Jana MM. (2015). Solid state fermentation with recovery of Amyloglucosidase from extract by direct immobilization in cross linked enzyme aggregate 
for starch hydrolysis. Biocatal. Agric. Biotechnol., 4: 486-492.

http://dx.doi.org/10.1016/j.bcab.2015.07.007

[24] Pahujani S, Kanwar SS, Chauhan G, Gupta R. (2008). Glutaraldehyde activation of polymer Nylon-6 for lipase immobilization: Enzyme characteristics and stability. Bioresour.

Technol., 99: 2566-2570.

[25] Roy N, Ray L, Chattopadhyay P. (2004). Production of lipase in a fermentor using a mutant strain of Corynebacterium species: Its partial purification and immobilization. Indian J. Exp. Biol., 42: 202-207.

[26] Dosanjh, N S and Kaur, J (2002). Immobilization, stability and esterification studies of a lipase from a Bacillus sp. Biotechnol. Appl. Biochem., 36: 7-12. 